\title{
Dry needling the masseter muscle in the treatment of myofascial pain: case reports
}

\author{
Agulhamento a seco no músculo masseter no tratamento da dor miofascial: relato de casos
}

Larissa de Oliveira REIS ${ }^{1}$, Diego Azi de OLIVEIRA ${ }^{1}$, Isabela Maddalena DIAS ${ }^{1}$, Isabel Cristina Gonçalves LEITE ${ }^{2}$, Fabíola Pessôa Pereira LEITE ${ }^{3}$

1 - School of Dentistry - Universidade Federal de Juiz de Fora (UFJF) - Bairro São Pedro - Juiz de Fora - MG - Brazil.

2 - Department of Public Health - School of Medicine - Universidade Federal de Juiz de Fora (UFJF) - Bairro São Pedro - Juiz de Fora MG - Brazil.

3 - Department of Restorative Dentistry - School of Dentistry - Universidade Federal de Juiz de Fora (UFJF) - Bairro São Pedro - Juiz de Fora - MG - Brazil.

\begin{abstract}
The aim of this study was to evaluate treatment with dry needling (AS) in the masseter muscle of patients diagnosed with myofascial pain as the pain symptoms and the mouth opening (AB). After sample size calculation, we selected 10 patients referred for treatment of temporomandibular disorders (TMD) diagnosed with MP, with or without limited mouth opening according to Axis I of the RDC/TMD, who underwent six DN sessions, once a week. Pain measurement using the Visual Analogue Scale (VAS) and an evaluation of the extent of mouth opening were done. All participants were female and the average age was 39.2 years, with $8(80 \%)$ having a diagnosis of myofascial pain with limited mouth opening and $2(20 \%)$ with only myofascial pain. Maximum unaided opening without pain before treatment was $31.9 \mathrm{~mm}$ and went to $36.2 \mathrm{~mm}$, and the maximum unaided opening went from $39.6 \mathrm{~mm}$ to $43.1 \mathrm{~mm}$. In both, however, could not find statistical significance $(\mathrm{p}>0.05)$. Regarding the mean weekly VAS value, this went from 8.3 before treatment to 2.3 a week later, with statistically significant results $(\mathrm{p}<0.05)$. In this study, the AS in the masseter muscle presented is a therapeutic alternative in the treatment of myofascial pain.
\end{abstract}

\section{KEYWORDS}

Temporomandibular joint; Temporomandibular Joint Disorders; Dry needling; Trigger points; Myofascial pain.

\section{RESUMO}

O objetivo desta pesquisa foi avaliar o tratamento com agulhamento seco (AS) no músculo masseter dos pacientes diagnosticados com dor miofascial quanto à sintomatologia dolorosa e a abertura bucal ( $A B)$. Após cálculo amostral, foram selecionados 10 deles, diagnosticados com dor miofascial com ou sem limitação de abertura pelo Eixo I do RDC/TMD, que foram submetidos a seis sessões de AS uma vez por semana. A sintomatologia dolorosa foi determinada semanalmente através da Escala Visual Analógica (EVA), e foi mensurada a $\mathrm{AB}$ sem auxílio e sem dor e a $\mathrm{AB}$ máxima sem auxílio antes do início do tratamento, e uma semana após o fim do mesmo. Ambas as médias foram analisadas através do ANOVA. Todos eram do gênero feminino e a média de idade foi de 39,2 anos, com 8 (80\%) possuindo diagnóstico de dor miofascial com limitação de abertura bucal e $2(20 \%)$ com dor miofascial somente. A abertura sem auxílio e sem dor antes do tratamento era de 31,9 $\mathrm{mm}$ e passou para $36,2 \mathrm{~mm}$, e a abertura máxima sem auxílio de 39,6 $\mathrm{mm}$ para 43,1 $\mathrm{mm}$. Em ambas, porém, não foi possível encontrar significância estatística (p $>0,05)$. Quanto ao valor médio semanal da EVA, este passou de 8,3 antes do tratamento, para 2,3 uma semana após o mesmo, com resultados significativos estatísticamente $(\mathrm{p}<0,05)$. No presente estudo, o AS no músculo masseter apresentou-se uma alternativa terapêutica no tratamento da dor miofascial.

\section{PALAVRAS-CHAVE}

Articulação temporomandibular; Transtornos da Articulação Temporomandibular; Agulhamento a Seco; Pontos-gatilho; Dor miofascial. 


\section{INTRODUCTION}

$\mathrm{T}_{\mathrm{r}}$ emporomandibular disorders (TMD) refers to a set of changes that affect the temporomandibular joint (TMJ) and/ or masticatory muscles and facial structures [1]. According to the Research Diagnostic Criteria for Temporomandibular Disorders (RDC/TMD), TMD can show up in a number of diagnoses, with the Muscle Disorders Group (Group I) comprised of two of them: myofascial pain and myofascial pain with limited mouth opening [2].

Myofascial pain (MFP) is a common diagnosis in patients with musculoskeletal pain associated with active or latent myofascial trigger points (TPs) [3]. The peculiar feature of TPs is that they are a constant source of deep pain and therefore may produce central excitatory effects, affecting the CNS [4]. Without intervention, local and referred pain can become chronic, and restricted motion and muscle weakness can occur [5]. Among the different treatment options, dry needling (DN) is an effective intervention used in the treatment of myofascial pain.

DN is a technique in which the introduction of a needle through the skin is done without the injection of any drug [6]. Its effectiveness may be based on the mechanical disruption of the integrity of dysfunctional endplates. It is suggested that these endplates would be where the TPs develop [7].

Although a recent therapy, existing studies on dry needling suggest considerable improvements in the symptomatological and functional evolution of the individuals involved3,5-7. This study aimed to evaluate treatment of dry needling in the masseter muscle, based on pain and mouth opening of the patients.

\section{MATERIALS AND METHODS}

This paper was submitted to the Ethics Committee on Human Research of the Federal
University of Juiz de Fora (Minas Gerais, Brazil) and approved an opinion 811.390/2014. All patients were asked to sign a free and informed consent form, in duplicate, ensuring the free participation in the study.

To carry out this experimental study, 25 (twenty-five) patients complaining of orofacial pain, referred to the Diagnostic and Advisory Service for Patients with Temporomandibular Disorder (TMJ SERVICE), School of Dentistry, Federal University of Juiz de Fora (Minas Gerais, Brazil), were evaluated. Of these, after a prior sample calculation, ten (10) patients matched the inclusion criteria of being between 18 and 70 years of age and having a myofascial pain diagnosis according to the clinical criteria of the RDC/TMD Axis I [2].

The diagnostic criteria for active and latent TPs established by Travell and Simons [8] were followed in this work. The exclusion criteria were patients who were undergoing another type of therapeutic protocol for MFP and patients with systemic diseases.

The tests were administered by a single calibrated examiner TMD expert.

In order to visualize the symptomatic evolution of the individuals in the sample, the assessment of physical symptoms was recorded at seven different moments in time:

- Moment 0 (M0): before treatment;

- Moment 1 (M1): one week after the 1st needling session;

- Moment 2 (M2): one week after the 2nd needling session;

- Moment 3 (M3): one week after the 3rd needling session;

- Moment 4 (M4): one week after the 4th needling session;

- Moment 5 (M5): one week after the 5th needling session;

- Moment 6 (M6): one week after the 6th needling session. 
In all the moments, each participant's pain intensities were measured according to the Visual Analogue Scale (VAS).

Before treatment (M0), through the RDC/ TMD, and after the end of treatment (M6), the extent of unaided mouth opening without pain and the extent of maximum mouth opening without aid, were evaluated, with both these measurements done according to question $4 \mathrm{a}$ of the RDC/TMD Axis I.

The 10 patients participating in the study were submitted to 6 weekly sessions of dry needling in the masseteric TPs. After cleaning with 70\% alcohol, the TPs were marked with a ballpoint pen. The needling was done with acupuncture needles (Dongbang Acupuncture ${ }^{\circledR T M}$, Boryeong, Chungnam, Korea), diameter $0.25 \times 30 \mathrm{~mm}$, and $5 \mathrm{~cm}$ in length. Upon positioning the apparatus (needle and insertion tube) on the marked point, the needle is manually pressed into contact with the trigger point (Figure 1). Smooth rotary motions with the needle were then made by the operator, tilting it in each direction, for 1 minute per point. It is suggested that this mechanical action can undo the trigger point in the muscle fiber [7,9] (Figure 2).

After collection, the data related to measuring pain intensity were analyzed. According to analysis of the seven moments, the mean of the individual symptomatic level reported by all patients was calculated, with the main purpose of comparing the level of pain of each patient and the entire sample, before and after treatment. Absolute and relative frequencies and descriptive measures for continuous data (mean and standard deviation) were obtained. The Kolmogorov-Smirnov test showed normal distribution of the quantitative measures $(p>0.05)$. The opening measures in the first session (M1) and one week after the end of treatment (M7) were compared, as well as the VAS means, through ANOVA $(\mathrm{p}<0.05)$. Statistical analysis of the results was done with SPSS 14.0 software.

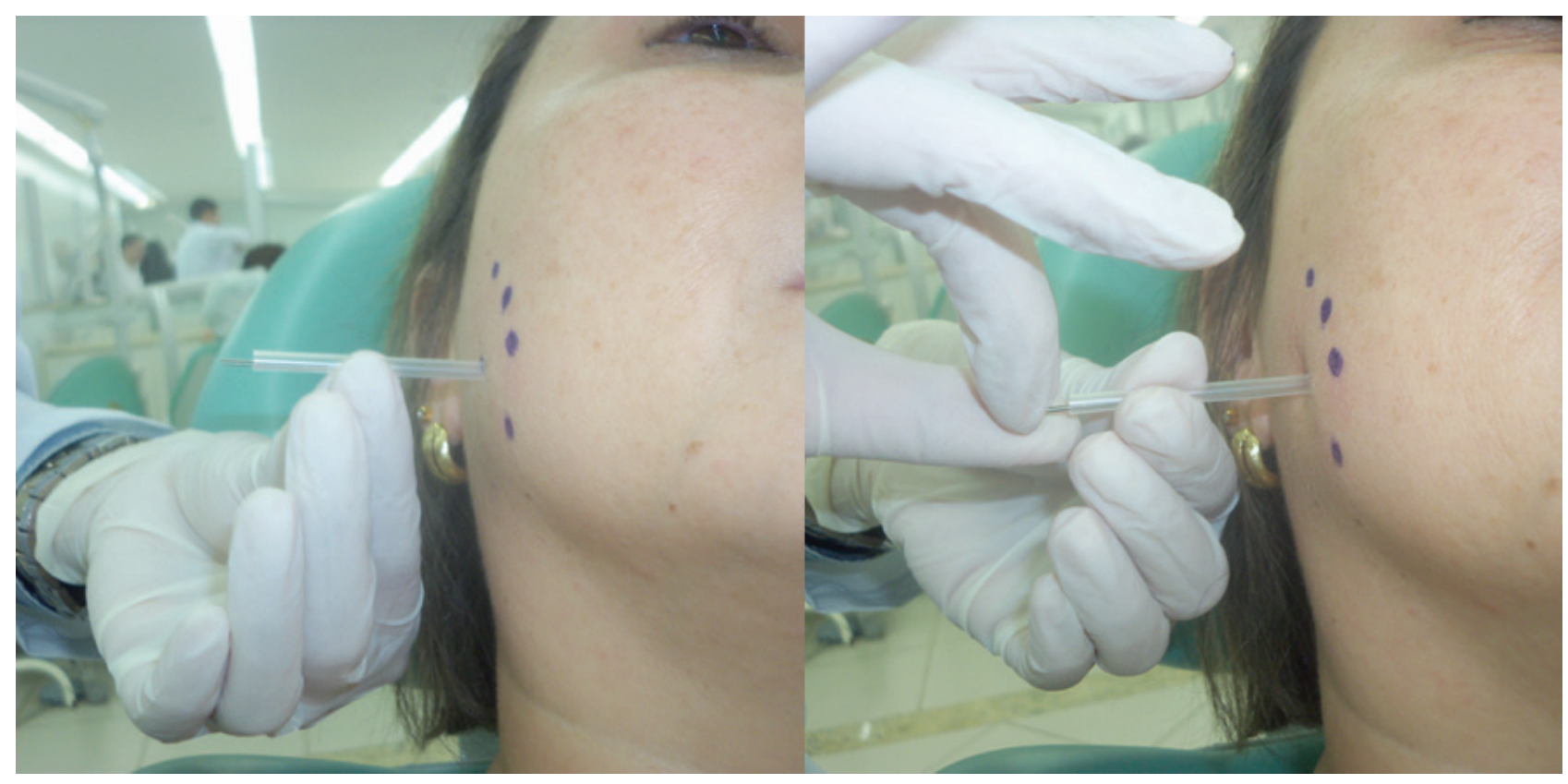

Figure 1 - Set supported the point and driven to manual touch to the contact of the needle with the trigger point (TP). 


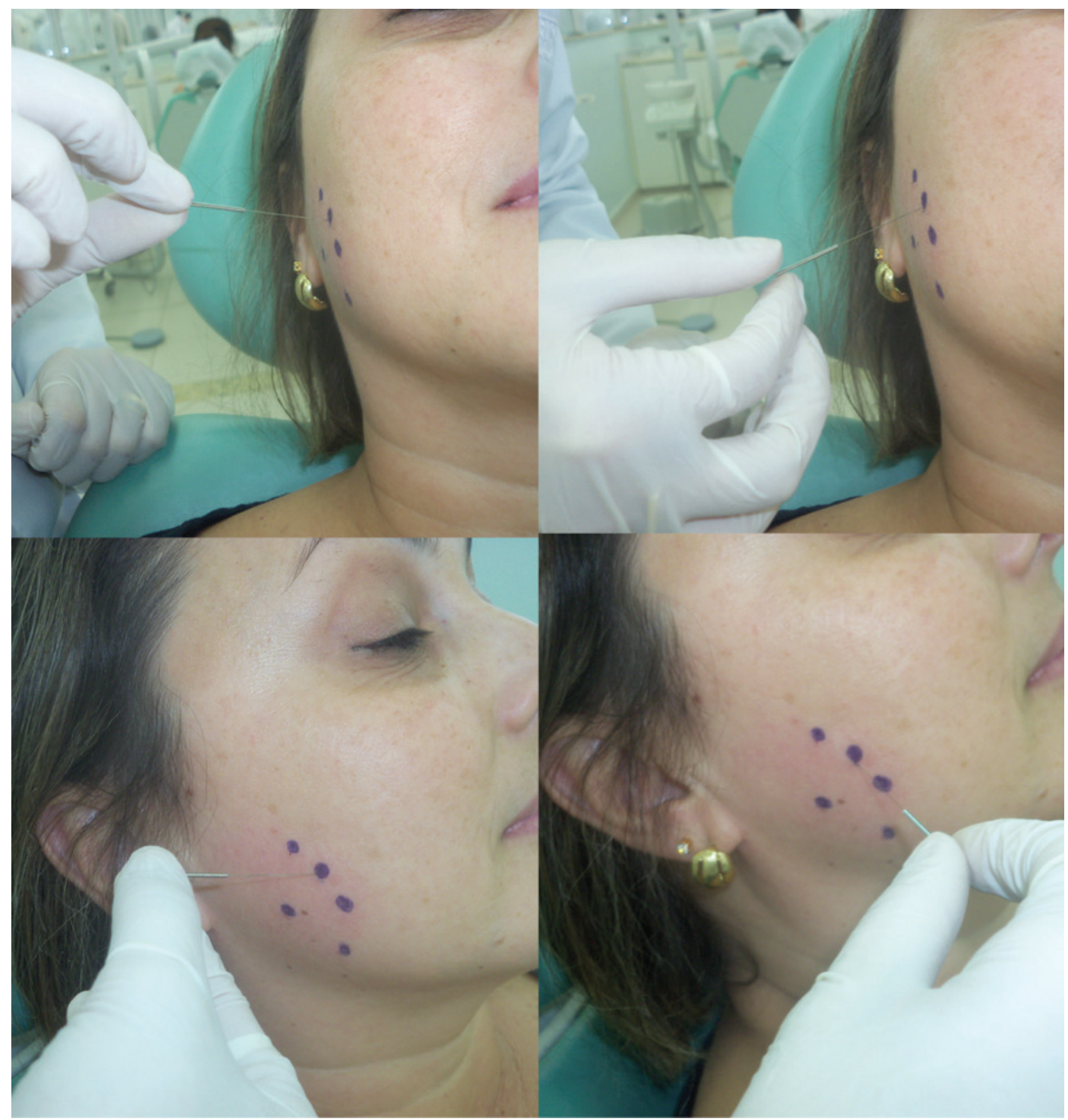

Figure 2 - Rotary movements made with the needle during dry needling technique.

\section{RESULTS}

The sample consisted of 10 patients, all female, between 24 and 56 years of age, with a mean age of 39.2 years.

As for the diagnosis of TMD according to Axis I of the RDC/TMD, 8 patients (80\%) had myofascial pain with limited opening, and 2 (20\%) had myofascial pain only. In addition, 4 patients (40\%) had arthralgia and $3(30 \%)$ had disc displacement with reduction.

The range of mouth opening without assistance and without pain before treatment 
varied from 23 to $42 \mathrm{~mm}$, with a mean of 31.9 $\mathrm{mm}$. While the same range after treatment was from 25 to $48 \mathrm{~mm}$, with a mean of $36.2 \mathrm{~mm}$. The range of maximum opening without assistance, even with discomfort, was from 32 to $49 \mathrm{~mm}$, with a mean of $39,6 \mathrm{~mm}$, before treatment, while after treatment it was between 32 and 52 $\mathrm{mm}$, with a mean of $43,1 \mathrm{~mm}$, but it was not statistically significant ( $p>0.05$ ).

As for the VAS, the weekly averages were evaluated for this measure reported by all patients. At M0, before the start of treatment, the mean value was 8.3 , moving to 5.5 at M1, 6.1 at M2, 3.3 at M3, 2.6 at M4, 3.4 at M5, and finally to 2.3 at M6, after the end of the sixth and final session. The difference between the VAS means for pain obtained at M0 and M6 represents a reduction of 6.0 points (Figure 3 ).

\section{DISCUSSION}

Statistically, a small sample $(\mathrm{n}=10)$ like this study would likely result in all subjects are female, as was the case. Martins et al. [10] state that due to both a muscular arrangement and to ligamentous laxity, women anatomically are more susceptible to the development of TMD. Okeson [11] states that women show more concern about their health and seek treatment more than men do, and therefore end up being more often reported. Furthermore, Ihla et al. [12] suggest that there is an increase of the symptoms of TMJ dysfunction in women due to estrogen and prolactin, which can exacerbate the degradation of articular cartilage and bone, as well as stimulate a series of immune responses in these joints.

The mean age of the individuals affected by MFP was 39.2 years, corresponding with Pereira et al. [13] who state that the most prevalent age range for TMD is 21-40 years. Furthermore, this agrees with the studies by Biasotto-Gonzalez [14] and Selaimen [15] that showed a high prevalence of TMD in the population studied, with the highest frequency of symptoms reported by individuals $20-40$ years old.

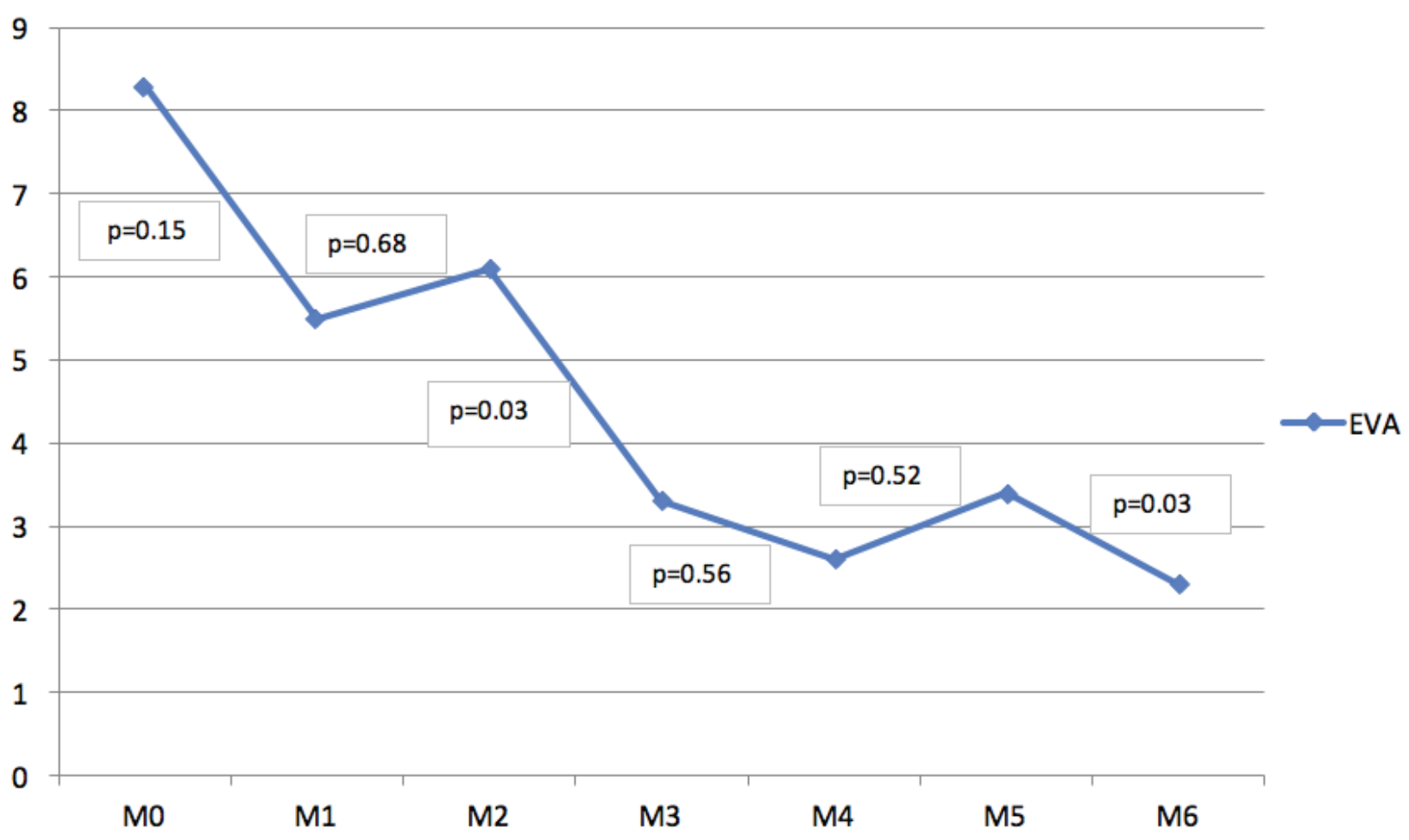

Figure 3 - Average EVA values according to the week of treatment. 
Even without obtaining a statistically significant increase $(\mathrm{p}>0.05)$ between the two mouth opening measures analyzed before and after treatment, Okeson [4] points out that besides the pain mentioned, other central excitatory effects due to the presence of TPs can be noted, such as protective co-contraction. In this situation, in the presence of any injury or threat thereof, the normal sequence of muscle activity appears to be changed to protect the threatened part. Furthermore, Antônia et al. [16] and Celik and Mutlu [11] state that myofascial pain may arise after episodes related to prolonged muscle contraction and restriction of movement, which could explain the clinical difference of unaided mouth opening without pain from maximum unaided opening, measured in the present study.

In the work by Uemoto et al. [6], which compared one group that received dry needling in the masseter muscle and another laser treatment group, a significant improvement in mouth opening was not obtained in either of them, a result that, as regards the group of seven persons undergoing the dry needling, corresponds with the present study. As suggested here in this work, since the therapy was applied only to the masseter muscle, this may not have provided relaxation to the jaw depressor muscles, and consequently, to the muscles responsible for opening the mouth, which agrees with the results from the aforementioned study. However, for Fernández-Carneiro et al. [5], the increase in maximum jaw opening without pain may indicate that $\mathrm{DN}$ can relieve the tension in the taut bands in the masseter muscle and thus facilitate mouth opening.

In the present work, dry needling therapy alone was used, however, as Maluf et al. [17] report, associated therapies can provide greater muscle relaxation, such as the combination of therapeutic exercises and postural re-education. Fernandes et al. [18] state that, to increase the amplitude of mandibular movement, physiotherapy exercises should be performed.

In addition, some patients in the present study had other TMD diagnoses besides myofascial pain, which may have affected the mouth opening value, as in the study by Hedge et al. [19], in which they state that disk displacement indicates a mechanical interference in the TMJ.

The weekly mean VAS value, when compared before therapy (M0) and one week after it ended (M6), was reduced from 8.3 to 2.3 points, demonstrating statistically significant results $(\mathrm{p}<0.01)$. In the study by Uemoto et al. [6] already mentioned above, only the needling group saw a significant symptomatological improvement regarding VAS ( $\mathrm{p}<0.05$ ), as was seen in the present work. In contrast, Casanueva et al. [20] submitted 120 fibromyalgia patients to dry needling treatment, with 60 of them in the control group and the other 60 in the experimental group. In that study, after treatment ended, a significant difference could be measured via the VAS symptomatic evaluation $(\mathrm{p}=0.002)$, which supports the present findings.

In the present study, it was found that the statistically significant improvement of symptoms measured by VAS occurred from M2 to M3 ( $<<0.05$ ), and was maintained upon comparing M0 with M3, M4, M5, and M6. The work of Casanueva et al. [20] corroborates this study, since it submitted 60 patients to a weekly DN session for six weeks, and obtained statistical significance in relation to VAS values before and after treatment $(\mathrm{p}<0.01)$. In the work by Ilbuldu et al. [9], 4 needling sessions were done, once per week, and a statistically significant $(\mathrm{p}<0.05)$ initial to final VAS difference was obtained. However, these authors did not do a weekly symptomatic assessment, thus not specifying when the improvement occurred in fact, as was done in the present study.

As mentioned above, TMDs present a diagnostic diversity that requires different therapies according to the patient's condition. Dry needling therapy is a treatment alternative for patients with myofascial pain, as suggested by the literature and as can be seen in the present study. We emphasize the importance of the professional's knowledge and proper 
execution of the technique. And on that basis, of establishing a specific treatment plan for each case, taking into account the psychological and clinical aspects of the disorders in order to alleviate the pain and minimize its negative impact on the individuals.

Thus, based on this study's results, it was found that dry needling the masseter muscle was treatment with statistically significant results in reducing the pain symptoms of patients with myofascial pain ( $\mathrm{p}<0.05$ ), although there was no statistically significant improvement ( $p$ $>0.05$ ) between the initial and final mouth opening range of the patients.

\section{REFERENCES}

1. Santana IL. Análise descritiva dos sinais e sintomas que relacionam Síndrome de Eagle e DTM: um estudo retrospectivo. Rev Ciênc Saúde. 2012;14(1):68-72.

2. Dworkin SF, Le Resche L. Research diagnostic criteria for temporomandibular disorders: review, criteria, examinations and specifications, critique. J Craniomandib Disord. 1992 Fall;6(4):301-55.

3. Cagnie B, Dewitte V, Barbe T, Timmermans F, Delrue N, Meeus M. Physiologic effects of dry needling. Curr Pain Headache Rep. 2013 Aug;17(8):348. doi: 10.1007/s11916-013-0348-5.

4. Okeson P. Tratamento das desordens temporomandibulares e oclusão. 7 ed. São Paulo: Artes Médicas; 2013.

5. Fernández-Carnero J, La Touche R, Ortega-Santiago R, Galan-delRio F, Pesquera J, Ge HY, Fernández-de-Las-Peñas C. Short-term effects of dry needling of active myofascial trigger points in the masseter muscle in patients with temporomandibular disorders. J Orofac Pain. 2010 Winter;24(1):106-12.

6. Uemoto L, Garcia MA, Gouvêa CV, Vilella OV, Alfaya TA. Laser therapy and needling in myofascial trigger point deactivation. $J$ Oral Sci. 2013;55(2):175-81.

7. Chou LW, Kao MJ, Lin JG. Probable mechanisms of needling therapies for myofascial pain control. Evidence-based complementary and alternative medicine. Evid Based Complement Alternat Med 2012;2012:705327. doi: 10.1155/2012/705327. Epub 2012 Dec 31

8. Travell J, Simons DG. Myofascial pain and dysfunction: the trigger point manual, upper half of body. 2 ed. Baltimore: Williams \& Wilkins; 1999.
9. Ilbuldu E, Cakmak A, Disci R, Aydin R. Comparison of laser, dry needling, and placebo laser treatments in myofascial pain syndrome. Photomedicine and Laser Surgery. 2004;22(4):306-11.

10. Martins RJ, Garcia AR, Garbin CAS, Sundefeld MLMM. Relação entre classe socioeconômica e fatores demográficos na ocorrência da disfunção temporomandibular. Ciênc Saúde Coletiva 2008;13(Suppl 2):2089-96.

11. Celik D, Mutlu EK. Clinical Implication of Latent Myofascial Trigger Point. Curr Pain Headache Rep. 2013 Aug;17(8):353. doi: 10.1007/ s11916-013-0353-8.

12. Ilha VCA, Rapoport A, Ilha Filho JB, Reis AA. Boni AS. Estimativa da excursão condilar em pacientes com disfunção craniomandibular: um enfoque multidisciplinar. R Dental Press Ortodon Ortop Facial. 2006;11(3):63-70.

13. Pereira KNF, Andrade LLS, Costa MLG, Portal TF. Sinais e sintomas de pacientes com disfunção temporomandibular. Rev CEFAC. 2005 Abr-Jun;7(2):221-8.

14. Biasotto-Gonzalez DA, Andrade DV, Gonzalez T0, Martins MD, Fernandes OS, Correa JCF, et al. Correlação entre disfunção temporomandibular, postura e qualidade de vida. Rev Bras Crescimento Desenvol Hum. 2008;18(1):79-86.

15. Selaimen C, Brilhante D, Grossi MI, Grossi PK. Avaliação da depressão e de testes neuropsicológicos em pacientes com desordens temporomandibulares. Ciênc Saúde Coletiva. 2007:12(6):1629-39.

16. Antonia MD, Oliveira Netto RM, Sanches ML, Guimarães AS Jaw muscles myofascial pain and botulinum toxin. Rev Dor. 2013;14(1):52-7.

17. Maluf AS, Moreno BGD, Alfredo PP, Marques AP, Rodrigues G. Exercícios terapêuticos nas desordens temporomandibulares: uma revisão de literatura. Fisioter Pesqui. 2008;15(4):408-15.

18. Fernandes WVB, Michelotto AB, Kimura S. Comparação entre Técnicas Osteopáticas e Fisioterapia Convencional para 0 Tratamento das Desordens Temporomandibulares. Rev Inspirar. 2009;1(1):28-32

19. Hegde S, Mahadev R, Ganapathy KS, Sujatha D, Patil BA. Prevalence of signs and symptoms of temporomandibular disorders in dental students. J Indian Academy of Oral Medicine and Radiology. 2011;23(3):316-9.

20. Casanueva B, Rivas P, Rodero B, Quintial C, Llorca J, González-Gay MA. Short-term improvement following dry needle stimulation of tender points in fibromyalgia. Rheumatol Int. 2014 Jun;34(6):861-6. doi: 10.1007/s00296-013-2759-3. Epub 2013 Apr 23.

\section{Larissa de Oliveira Reis \\ (Corresponding address)}

Sítio Córrego Santana, s/nº, Zona Rural,

Guiricema, Minas Gerais.

School of Dentistry - UFJF. Bairro São Pedro

Juiz de Fora, Minas Gerais.

CEP: 36525-000.

Date submitted: 2016 Sep 05

e-mail: larissadeoreis@gmail.com Accept submission: 2017 Apr 10 